\title{
Investigating into the problems of writing in English Language: perspective of tertiary level students
}

\author{
Md. Shamim Hossain Biswas* \\ * Department of English, North South University \\ DOI: 10.29322/IJSRP.11.06.2021.p11444 \\ http://dx.doi.org/10.29322/IJSRP.11.06.2021.p11444
}

\begin{abstract}
The aim of this research was to investigate students' writing problem among tertiary level students of DEML (Department of English and modern language) at NSU- One of the leading private universities in Bangladesh. A mixed method research approach was applied: qualitative and quantitative. A survey questionnaire, focus group discussion, and an interview protocol were designed for collecting data. The population of this research were tertiary level students and from where 20 students were selected as a sample of quantitative data collection and in qualitative data collection, 10 students were participated on online interview and at digital focus group discussion. The questionnaire consists of 52 survey questions, 30 interview questions, and 10 themes for group discussion. The survey questions consist of 13 type's problems with 5 alternative answers. SPSS (Statistics package for social science) was used to analyze the data. Writing problems were categorized into two main types: Mechanical problem and Rhetorical problem. Research revealed that students face 13 types of writing problems in total: 5 types writing problems in mechanical grammar and 8 types writing problems in rhetorical grammar. The overall mean of tertiary level students' writing problems was $(X=3.74038)$ that leveled as "low problem". It was observed that university students' problems in punctuation were $(X=3.4875)$, problems in purpose $(X=3.2625)$, problems in audience $(X=3.225)$. All the four categories are leveled as 'Medium' for university students. All other problems were leveled as 'low problems'. It means students did not have too many problems in terms of using mechanical grammar and rhetorical grammar in their writing.
\end{abstract}

Index Terms- mechanical grammar, rhetorical grammar, L2 writing problems, qualitative research, quantitative research, mixed method research, statistical data analysis, thematic data analysis, inductive coding, mean score, SPSS

\section{INTRODUCTION}

$\mathrm{E}$ nglish language is an excellent instrument for scientific communication. It is an international communicative language. If anyone wants to contribute their ideas among global scholars, he or she needs to have expertise in English language. One of the aims of learning English as a L2 is to develop a global communication skill. English language consists of four skills: Listening, speaking. Reading, and writing. Writing is one of the most complicated skills. It is an essential skill for both teacher and students. A good writing comes from prewriting, writing, and rewriting habits (Bonjour \& Manuel, 2016). Writing is a process and it is considered a productive skill that is the most difficult task for students to communicate and ESL students face difficulty to earn this ability to become proficient in writing (Chamba et al., 2019). Writing is not a gift but learned skill; this communication competence can be acquired by engaging academic writing activities. Writing skill is related to extensive reading. Many things need to be done in order to achieve writing skill and one of them is critical thinking about mechanical-grammar and rhetorical-grammar. These grammatical aspects are required for effective English writing. Grammar makes writing more meaningful and more readable (Johnson, 1996). Writing is thought to be the creative and intellectual property of an educated person, compared to other three language skills.

Academic writings are categorized into four types: persuasive, descriptive, critical, and analytical writing. Besides those some other types of writings are narrative, persuasive, scientific, expository, scientific, and technical writing. It is a difficult task for learners to achieve competency in all areas of writing. This study was conducted only for identifying academic writing difficulties among tertiary level students of NSU (North South University) in Bangladesh. This is not a new investigation, but many researchers also have a deep interest in conducting repetitive research in this topic in order to identify a genuine figure for L2 writing problems. The motivation of conducting the research in this topic is none of them $100 \%$ perfect. Many tertiary level students have been facing L2 writing problems. That is why it is urgent to find problems and design plans to solve writing problems accordingly. The purpose of this research is to identify the causes of writing problems and to be aware of student's writing problems.

The importance of this research in Bangladeshi academic context is immense. Most of the tertiary level students in our country come from various streams like science, commerce, and engineering. These students take English course as an elective one. As a result they 
can hardly pay attention to the English language. Even though the medium of instructions in teaching of Bangladeshi private universities is English, many students cannot be proficient in L2 writing. Their understanding regarding text and writing skill is below the satisfactory. Because, students are accustomed to a lot of memorization information gathering. This tendency creates a psychological barrier in their thinking ability. At the undergraduate level, nowadays English has been used as the medium of instruction and the students have to write everything in English. The students who come from Bangla medium backgrounds have writing difficulties. A number of reasons are responsible for these conditions. But it is possible to minimize their L2 writing problem if tertiary level students can be proficient in mechanical grammar and rhetorical grammar. The current study is expected to minimize English writing problems. The study is conducted with the hope that it will be helpful for students because it provides deeper information and knowledge about L2 writing difficulties.

The road map of this research has been organized as the first section is introduction section, the $2^{\text {nd }}$ sections consists of literature review, the $3^{\text {rd }}$ section contains research methodology, the $4^{\text {th }}$ section represents results of the study, the $5^{\text {th }}$ section is for discussion, and finally the $6^{\text {th }}$ section contains conclusion, limitation, and recommendation.

\section{LITERATURE REVIEW}

\section{A. L2 Learning}

One of the aims of learning English as a second language is to develop a global communication skill. L2 learning refers to L2 acquisition (Wikipedia, 2021). Language is egalitarian. No language is a protocol legalized by an authority. Every language is an organic product of human creativity. Every generation create a new language. Every language has generation gap-after every 10 years, human belief and language's code of conduct change a bit. Language is generative and creative. Language is dynamic, flexible, different, and varies. Some language has different meaning and connotation. Every racial identity has different language. Students use sophisticated version of language. The sophisticated version of language is not their own language. The sophisticated version of language is a language that teachers teach students. Students pick up that language from book, teachers or who is intellectually superior. Only communication is not the purpose of language. Language persuades, inspires, misinforms, prays, and propagates. Language transmits idea, information. Language provide insights about information. Language has so many purpose that language serves. Good language unites, clarifies, and inspires the human society. English language skill consists of four skills: Listening, speaking. Reading, and writing. Writing is one of the most difficult and complicated skills. It is a learned skill because writing requires critical thinking about mechanical-grammar and rhetoricalgrammar. These two main grammatical aspects are required for effective and communicative English writing.

\section{B. L2 Writing}

Writing is a learned skill. "Writing is an intellectual achievement" (Zamman, 2019). It is an artificial and conscious process; it requires systematic selection and organization of speech. Writing is semantic rather than lexical. Semantic deals with meaning and that is made by thinking. Writing is related to thinking (Zamman, 2019). Writing is not word dependent instead it is meaning dependent. We do not write with words. We write with ideas that are symbolized in words. Meaning is created by thinking where thinking is a metacognitive process. Words convey meaning but it does not create meaning. Writing cannot defend itself. It spreads indiscriminately and destroys memory. Written language needs more grammar than spoken language. Grammar is a nonnegotiable requirement for writing (Zamman, 2019). Writing makes us cognitively more advanced and reflective. Without thinking, one can speak but one cannot write without thinking. The three conditions are required for writing: writing should be grammatical, graceful and transparent. For instance we cannot exist without breathing, in the same way writing does not exist without grammar. According to (Hamer, 2004), writing stimulates the brain of learners. Since writing itself enhances students' ability to use appropriate language, they can access their own mind.

\section{L2 writing problems}

Many students cannot write well even after achieving a dozen degrees because of bad education policy. Some students cannot comprehend many complex sentence patterns of English language and that is why they face problems in understanding. Psychological problems are one of the major problems in terms of L2 writing. Personality problems are a big problem in effective writing. Physical and mental soundness affect the writing. The meaning of process and product in the perspective of writing are imagination, cognitive skills, organization skills, drafting and editing, reading and reviewing, etc. The process of writing is cyclical and patience oriented. Finally, metacognitive skills are required to be an efficient writer. Students usually face difficulties in terms of applying mechanical grammar and rhetorical grammar in their writing. The writing 
problem can be reduced by creating intensive reading and writing habits, by ensuring effective teaching, by joining in discussion and debates, and by watching culture related drama and cinema (Raimes, 1983). Students have problems in differentiating topic sentences and supporting ideas. The topic based on specific details and generalizing the ideas are not the same at all. There is a cross connection between students' learning and teachers' teaching. Just as students benefit from good teaching of a good teacher, students also get demotivated from their goal due to bad teaching of a bad teacher. There are some ignorant students who do not follow teacher advice as a result they fail to reach in writing goals. I found a number of writing problems during literature review: According to Afrin (2016), Students had problems with paragraph constructions, problems in organizing ideas, coherence and cohesion language" (p. 107). In addition to that several problems in student's writing were noticed such as. "Grammatical mistakes, fragments, subject-verb-agreement, punctuation, spellings, capitalizations, articles, prepositions" (p. 107).

\section{i. Mechanical problem}

Mechanical grammar is usually the prescriptive version of grammar. Prescriptive grammar is a very specific type of grammar that talks about right and wrong versions of language or do's and don'ts of a language (Msanjila, 2005). Prescriptive grammar deals with two things: mechanics of language and pragmatics of language. In the Mechanical part, students usually face punctuation problems, indentation confusion, spelling errors, capitalization mistakes, and grammatical errors. In punctuation, some students use irrelevant apostrophe in their writing. Sometimes students use unnecessary single and double quotation marks. They do not know the necessity of quotation marks. At the placement of quotation marks, some students unintentionally put the full stop that goes outside the quotation mark at the end of sentence. Sometimes semicolon and colon are misused in the students' writing script. One study found that the main reason for spelling errors is irregularities of word spelling and it requires more effort to memorize (Joyousi, 2011). Capitalization rules are not universally standardized. Capitalizing the word classifying the proper noun and common noun is also a big headache for students (Gower et al, 1995). Students become confused and frustrated when they cannot construct proper syntax to express their thoughts in the writing (Hamer, 2001). Many university level students have mechanical problems (Alfaki, 2015; Karim, et al., 2017). In addition, many tertiary level students also face difficulties in using prepositions; they have lackings in tenses.

\section{ii. Rhetorical Problem}

Rhetorical grammar is an abstract grammar- invisible and inscrutable grammar. It makes good writing or speech better. Rhetorical grammar gives us the option to change sentences without changing meaning and grammar. It helps getting things right instead of talking about right and wrong. There are eight dimensions of rhetorical grammar: idea, argument, voice, word choice, sentence fluency, presentation, audience, and purpose.

- Idea- unique perspective. Idea is something which is different, unique and dances with dazzles. A thought has to become an idea. It has to be a new-original, unique idea that does not mean mere thought. It has some diversity, uniqueness. Many students do not know idea generation techniques-how to generate idea, support idea, and elaborate idea (Rahman, et al.,2019); some students do not have ability create a topic sentence; a number of students do not have paragraph organization skill (how to develop the beginning part, middle part and end of the paragraph); a handsome students have difficulties in writing styles (appropriate language application according to context considering the purpose and audience), some other students do not have adequate knowledge about academic writing convention-correct sentence formation (Hamer, 2004; Oshima et al, 2007). A good idea belongs to creative persons. The good idea is the soul of writing. It brings reader attention into the text. The important part of a paragraph is main idea. The main idea can be directly stated or may be untraceable. The supporting ideas are reasoned discourse, examples or evidence that elaborates the main idea in details. One of the biggest challenges of supporting the main idea is to provide sufficient evidence in order to transparent the main idea in a limited time.

- Word choice refers to semantic sophistication. It means writing words should be sugar coated. Hamer (2001) said that students become confused and frustrated when they cannot remember semantically sophisticated words to express their thoughts in writing. Some of the tertiary level students have word choice confusions ( Alfaki ,2015; Karim, et al., 2017).

- Argument is a reasoned discourse. It has to be logically fine-grained. It has to be logical and ethical. It is not condescending, confrontational, aggressive, and assertive. It should be informative, insightful language. It should have some academic flavor. It should have an ethical foundation. Academic arguments never become informal. In argumentation, one should attack the language instead of person.

- Voice is individual opinion, perspective. Voice refers to the author's signature in writing. Signature refers to uniqueness and distinctive style in writing. Every voice is not counted because it needs to be intellectually, ethically, and rhetorically unique. It is educational and intellectual achievement. 
- Sentence Fluency - a fluent sentence should be precise and concise. The sentence complexity depends on crafting or construction of sentences. Long sentences can be graceful and transparent. A complex sentence can be a piece of art if it can be constructed transparently. Sometimes comprehension or understanding problems arise for complex sentences. So it is better to write short sentences if someone has difficulties in crafting complex sentences.

- Presentation means the process of academic writing. Presentation in academic writing conveys messages from one speaker to a thousand speakers. Academic writing process refers to present ideas in a rational way, logical way, reasonable way, systematic way, and organized way. Presentation of writing determines style, layout of document, and use of authentic language.

- Purpose refers to reason for writing. It amuses, persuades, and informs the readers.

- Audience refers to the people who will read what has been written.

In addition to the mechanical grammatical problems and rhetorical grammatical problems of the tertiary level students, they also have psychological and social problems that affect the quality of writing. According to Alfaki (2015), a number of tertiary level students have cognitive problems, Graphomotor problem, paragraph unity problem, linguistic problems, and psychomotor problems. One study found that students have some other problems besides mechanical grammar and rhetorical grammar and those are "untrained teacher, ineffective teaching method, examination system, lack of reading and writing practice, large classrooms, low motivations and lack of ideas" (Fareed, et al., 2016, p.81). According to Karim, et al. (2017), student have "lack of pre-writing techniques, problem of content development" (p. 298). Another study found that some of the tertiary level students have psychological problems that damage their writings: "lower-level behavioral problem, higher-level behavioral problem, lack of attention for lessons, the sense of superiority over others, unsocial status, noise making tendency, overcrowding classroom, overloaded student in the classroom, disciplinary problem" (Naima, 2014). Based on discursive analysis of other people's findings in different contexts. My research is focusing on what kind of writing problems students face at university. To see thoroughly what are reasons behind the writing problems among tertiary level students.

\section{Aim and Objectives}

Overall research focus or the overrated goal of the current research is to investigate, formulate, and explore the L2 academic writing problems among tertiary level students in Bangladesh. And therefore the following research questions have been formulated from research objectives to conduct the study.

\section{Research Questions:}

1. What are the problems of writing in English language among university students in Bangladesh?

2. How tertiary level students overcome the writing problems in English language and what steps can be taken?

\section{RESEARCH METHODOLOGY}

As this study is to explore and understand different writing problems in Bangladesh at the tertiary level students and to see thoroughly what are reasons behind the writing problems among tertiary level students. In the previous section, there is a literature review of peer reviewed journal articles about the L2 writing problems and the cause of learners' writing problems. In this research methodology section, step-by-step research procedures are presented by which the research is conducted. In the first section, a brief summary of research design is presented. Data collection procedure is discussed in the second section. The third section presents a data analysis procedure.

\section{A. Research design}

The current study followed a mixed method research paradigm where both qualitative and quantitative research approaches were employed to collect data or to gather information. A mixed method research paradigm for this research can be visualized by following tabular representation:

Table I: A Mixed Method Research Paradigm 


\begin{tabular}{|c|c|c|c|}
\hline Method & Strategy & Data analysis technique & Participants \\
\hline $\begin{array}{l}\text { Mixed method- } \\
\text { Qualitative and } \\
\text { Quantitative approach }\end{array}$ & $\begin{array}{l}\text { - Qualitative: Focus } \\
\text { group discussion, semi- } \\
\text { structured interview, } \\
\text { - Quantitative: survey } \\
\text { questionnaire }\end{array}$ & $\begin{array}{l}\text { - Qualitative: Thematic } \\
\text { data analysis } \\
\text { - } \text { Quantitative: Statistic } \\
\text { data analysis } \\
\text { (descriptive statistics) }\end{array}$ & 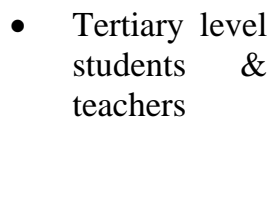 \\
\hline
\end{tabular}

The data were generated following three consecutive steps: 1). Survey Questionnaire, 2). Focused group discussion, and 3). Semistructured interview. Table I presents the profile of stakeholders who joined in semi-structured interviews and focused group discussions. Their identity is not presented due to ethical considerations. So participant's anonymity and confidentiality are maintained by using coding techniques.

Table II: Information of study participants for interview and group discussion

\begin{tabular}{cccl}
\hline Participants & Gender \&Age & Qualification & Institution \\
\hline EST01 & M/30 & MA in TESOL & Private University \\
EST02 & F/27 & MA in TESOL & Private University \\
EST03 & M/39 & MA in Linguist & Private University \\
EST04 & M/28 & MA in Literature & Private University \\
EST05 & F/20 & BA (Hons) & Private University \\
EST06 & F/24 & BA (Hons) & Private University \\
EST07 & F/23 & BA (Hons) & Private University \\
EST08 & $\mathrm{M} / 29$ & BA (Hons) & Private University \\
EST09 & F/26 & BA (Hons) & Private University \\
EST10 & $\mathrm{M} / 27$ & BA (Hons) & Private University
\end{tabular}

I as a researcher used a set of questionnaires as an instrument for conducting this research.

\section{B. Data Collection procedure}

The task of data collection and its interpretation followed three consecutive steps: Survey questionnaire, 2. Semi structured interview, and 3. Focused group discussion. Table III presents the data collection methods concerning the research questions.

Table III: Data collection method concerning the research questions

\begin{tabular}{|l|c|c|}
\hline \multicolumn{1}{|c|}{ Research Questions } & $\begin{array}{c}\text { Data Collection } \\
\text { Method }\end{array}$ & $\begin{array}{c}\text { Data } \\
\text { Source }\end{array}$ \\
\hline $\begin{array}{l}\text { 1. What are the problems of writing in English language among } \\
\text { university students in Bangladesh? }\end{array}$ & $\begin{array}{c}\text { Survey } \\
\text { Questionnaire, } \\
\text { 2. How tertiary level students overcome the writing problems in } \\
\text { English language and what steps can be taken? }\end{array}$ & $\begin{array}{c}\text { Level } \\
\text { Interview \& Focus } \\
\text { Group Discussion }\end{array}$ \\
$\begin{array}{l}\text { Students } \\
\text { at NSU }\end{array}$
\end{tabular}

\section{i. Semi-structured interview protocol}

The qualitative research methods facilitates in-depth, broad and comprehensive understanding of any research context and helps to produce rice, thick ,undocumented or obscure knowledge about the topic. The topic of this research suggests to find out L2 writing problems among tertiary level students. To analyze qualitative data, thematic data analysis technique was used. A semi-structured interview protocols and open-ended questionnaires were designed to collect data. Different meetings were arranged to collect interview data and the researcher did not follow stick rules; rather participants were asked open-ended questions and they were allowed to discuss with the researcher and they shared their L2 writing difficulties. Participants had given their interview through messenger in Bangla and their interview excerpts were digitally recorded. I prepared an interview protocol (IP) with three sections: introductory part, demographic section, and 
interview questionnaire. I distributed an interview questionnaire to the respondents through email before conducting the interview.

\section{ii. Focus Group Discussion (FGD)}

In a focused group discussion session, the ten learners who are studying BA hons and MA at NSU of Bangladesh participated. To know about their views of L2 writing difficulties, the discussion session was conducted for an hour which helped the researcher to explore L2 writing difficulties according to their opinions. It was a digital discussion and their conversations were digitally recorded.

\section{iii. Survey Questionnaire}

I used survey approach to collect data from tertiary level students about their writing problems. As I collected data from the same university like NSU, I used snowball sampling technique. I employed statistical data analysis technique. To analyze quantitative data, I used SPSS as a statistical data analysis technique. I designed a survey questionnaire using Google forms and then I sent the link of the form to the students through email and messenger. The questionnaire is a data collection instrument that each research participant participates in the questions answering sessions (Johnson \&Christensen, 2008). By using this technique, research respondents' perceptions and beliefs are obtained.

\section{Data Analyzing Procedure}

This study follows the mixed method research paradigm. Since the study's goal was to produce and interpret students' insights and perspectives through semi-structured interview data and focused group discussion. Other goal was to find out L2 writing problems among tertiary level students. The data was analyzed using SPSS and a step-by-step inductive thematic data analyses process. Numerous readings of the interview and discussions' transcripts made it easier for the author to assign descriptive codes to data extracts that were both interesting and important to the research issue. These codes were examined and refined to group them into groups. There was a deliberate effort to allow themes to emerge organically from the data (Nur, 2018). Different themes emerged from the overall data review process, which is summarized in the findings section (Short \& Nur, 2020).

\section{i. Thematic Data Analysis Technique}

To analyze qualitative data, I followed thematic data analysis technique. The figure 1 present the process of analyzing the qualitative data which were collected from semi-structured interview and focused group discussion.

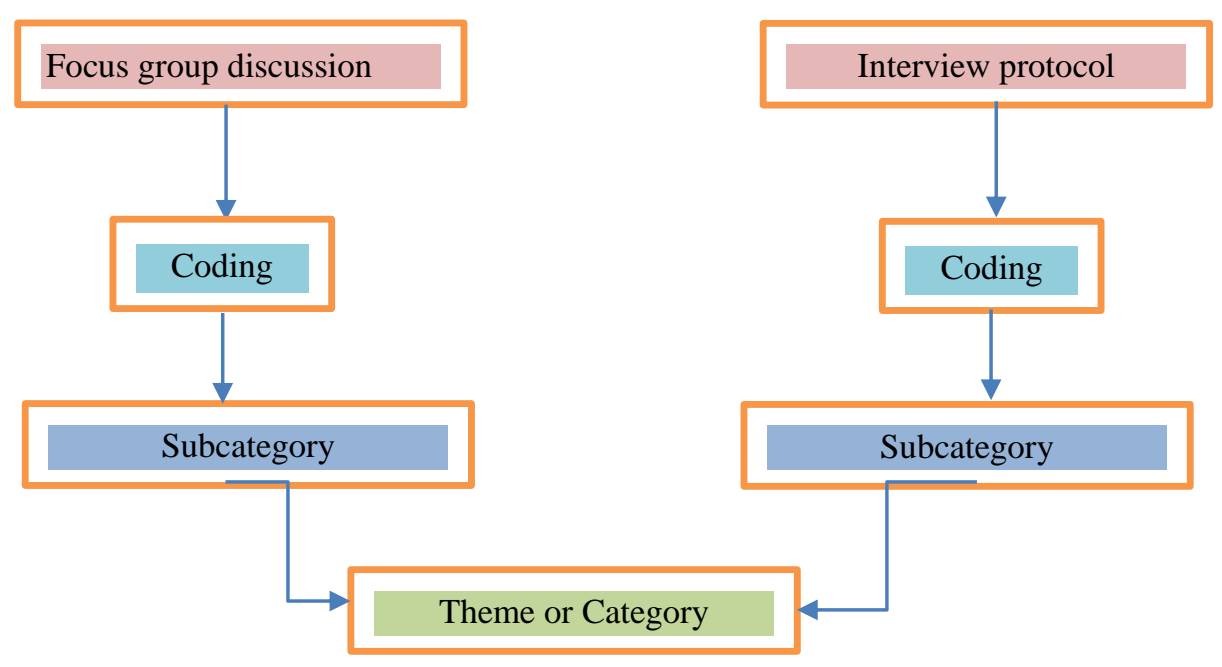

Figure 1: Qualitative data analyzing procedure

Coding technique is used to label and organize qualitative data in order to identify various themes and connection between them.

\section{ii. Statistical Data Analysis Technique}


Data analysis is the systematic process to evaluate and elaborate data. Descriptive data analysis technique is more efficient to calculate numerical data (Dornyei, 2003). To analyze statistical data, I used SPSS. I used a five point Likert scale to investigate tertiary level students' writing problems. There were five options for each likert scale and points were distributed manually: Strongly Disagree (D) with 1 points, Disagree (D) with 2 points, Neutral (N) with 3 points, Agree (A) with 4 points, and Strongly Agree (SA) with 5 points. Research participants selected one of the options from these five options by giving a checklist mark $(\sqrt{ })$. By using SPSS (Statistical Package for Social Science), I have calculated the mean score from the responses of research participants and then interpreted them proposing the following scale:

Table IV: Interpretation of Mean Score

\begin{tabular}{ccc}
\hline Range & Mean Score & Interpretation \\
\hline $1^{\text {st }}$ & $1.0-2.34$ & Very High Problem \\
$2^{\text {nd }}$ & $2.35-2.99$ & High Problem \\
$3^{\text {rd }}$ & $3.00-3.59$ & Medium \\
$4^{\text {th }}$ & $3.60-4.14$ & Low Problem \\
$5^{\text {th }}$ & $4.15-5.00$ & Very Low Problem \\
\hline
\end{tabular}

After data analysis, the results and discussion were presented

\section{RESULT ANALYSIS}

This section discusses the results found by interviews, focus group discussion with 10 tertiary level students, and survey questionnaires with 20 tertiary level students of Bangladesh. It was difficult to know the exact cause of L2 writing difficulties. However, different valuable perceptions were found for the journey of L2 writing problems among tertiary level students. During the interview, and focus group discussion 10 university students were asked to share their L2 writing difficulties. On the other hand, 20 university students participated in the survey questionnaire to give their perception on L2 writing problems. The different reasons for L2 writing difficulties are found and some activities were considered to minimize their English writing problem. In place of students' names, codes were used to present the data. For example, EST00 applies to a student interview and focus group discussion. The interview data that was translated into English after the interview. For the interview questionnaire, I prepared 32 questions. All the answers of the questions were not satisfactory for thematic analysis because all of them did not carry any theme. The Table V and VI show the list of causes of L2 writing problems among tertiary level students in Bangladesh. The details of the students' responses have been grouped according to the theme that emerged from the data. The emerging trends from the data analysis are listed below, along with supporting excerpts (Short \& Nur, 2020). The process of developing themes from interviews and group discussions is given in the following tables (V, VI) and finding them from subcategories are mentioned in figure 1, and finally, the discussion is written according to interview extracts, group discussion, and survey questionnaire.

Table V: An example of coding theme from interview

\begin{tabular}{|c|c|c|}
\hline participants & Extracts & Coding \\
\hline EST01 & $\begin{array}{l}\text { I usually face problems while I think of writing something or some } \\
\text { concept in my head, I think it in Bengali first and then I translate it } \\
\text { into English. I'm not rich in vocabulary. I run out of vocabulary while } \\
\text { writing. I tend to use simple and easy words. }\end{array}$ & $\begin{array}{l}\text { GTM, } \\
\text { Semantic } \\
\text { sophistication }\end{array}$ \\
\hline EST02 & $\begin{array}{l}\text { We all learn more or less basic grammars, but when it comes to } \\
\text { Standard grammar, I face problems in complex sentences, when we } \\
\text { want to stretch a sentence using multiple grammar in a sentence. }\end{array}$ & Sentence fluency \\
\hline EST03 & $\begin{array}{l}\text { I think our educational system is responsible for these difficulties, our } \\
\text { syllabus involves only basic and traditional grammars, and this does } \\
\text { not help in learning writing or speaking. }\end{array}$ & $\begin{array}{l}\text { Inefficient education } \\
\text { system }\end{array}$ \\
\hline$\cdot$ & . & \\
\hline . & & \\
\hline
\end{tabular}




\begin{tabular}{|l|l|l|l|l|}
\hline EST10 & $\begin{array}{l}\text { I think I don't have that much of an opportunity to practice and to get } \\
\text { exposed myself into English speaking and writing society. This } \\
\text { causes most of the Problems. The only solution I can think of right } \\
\text { now is to practice more and more and write more and more. Self- } \\
\text { evaluation is important in this case. }\end{array}$
\end{tabular}$\left|\begin{array}{c}\text { Necessity of self- } \\
\text { evaluation }\end{array}\right|$

From Table V, it was observed that students mainly faced vocabulary problems and sentence fluency. Sometimes they get stuck in GTM.

Table VI: An example of coding theme from focus group discussion

\begin{tabular}{|c|c|c|}
\hline Codes & Subcategory & $\begin{array}{l}\text { Category/ } \\
\text { Theme }\end{array}$ \\
\hline $\begin{array}{l}\text { Problems in starting sentences and supporting sentences. } \\
\text { Getting stack into supporting idea } \\
\text { Problem in opening sentence and concluding sentence. } \\
\text { Inability to connect two separate paragraphs. } \\
\text { Not able to bring relevant thought }\end{array}$ & $\begin{array}{l}\text { Topic sentence } \\
\text { Supporting sentences } \\
\text { Supporting details }\end{array}$ & $\begin{array}{l}\text { Paragraph } \\
\text { writing } \\
\text { Problem }\end{array}$ \\
\hline $\begin{array}{l}\text { It takes long time to provide personal view point } \\
\text { Unable to connect relevant thought } \\
\text { Unable to find out relevant example in order to support main idea } \\
\text { The device of supporting ideas are unknown }\end{array}$ & $\begin{array}{l}\text { Main idea } \\
\text { Idea generation problem } \\
\text { Supporting idea }\end{array}$ & Idea \\
\hline $\begin{array}{l}\text { Unable to be logical and consistent in writing } \\
\text { Facing difficulties in connecting idea at idea level } \\
\text { Inability to connect idea into sentence levels }\end{array}$ & $\begin{array}{l}\text { Lack of knowledge of } \\
\text { cohesive devices } \\
\text { Coherence difficulties } \\
\text { Cohesion difficulties }\end{array}$ & $\begin{array}{l}\text { Coherence \& } \\
\text { Cohesion }\end{array}$ \\
\hline $\begin{array}{l}\text { Problem in figurative language } \\
\text { Confusion in get used to, used to, } \\
\text { Problem of using a group of words or phrases or expressions that } \\
\text { mean together in a sentence. } \\
\text { Fail to connect multiple independent clauses together } \\
\text { Problem of using same grammatical structure or repeating } \\
\text { grammatical form or noun phrases in more than one sentences }\end{array}$ & $\begin{array}{l}\text { Idiomatic problem } \\
\text { Prepositional problem } \\
\text { Idiomatic expression } \\
\text { Run -on sentence } \\
\text { problem } \\
\text { Parallelism or parallel } \\
\text { structure }\end{array}$ & $\begin{array}{c}\text { Grammatical } \\
\text { mistakes }\end{array}$ \\
\hline $\begin{array}{l}\text { Students often fail to write a complete sentence } \\
\text { Lack of knowledge on advanced fragment } \\
\text { Failure to connect multiple independent clause } \\
\text { Difficulties in crafting a sentence matching subject and verb. }\end{array}$ & $\begin{array}{l}\text { Sentence completion } \\
\text { problem } \\
\text { Clause linking problem } \\
\text { Verb takes place } \\
\text { depending on subject }\end{array}$ & $\begin{array}{l}\text { Fragment } \\
\text { Run-on } \\
\text { Subject vs } \\
\quad \text { verb } \\
\text { agreement }\end{array}$ \\
\hline $\begin{array}{l}\text { Carelessness is the cause of wrong spelling } \\
\text { Difficulties in colon, semicolon, apostrophe, } \\
\text { Sometimes it is difficult to follow the rules of capital Letter } \\
\text { Inability to qualify a statement or claims } \\
\text { Problem in remembering and recognizing words and its spelling } \\
\text { Inability to move forward during writing } \\
\text { Difficulty in paying attention while writing } \\
\text { Long time is required for completing writing task } \\
\text { Slowing down of thought during writing }\end{array}$ & $\begin{array}{l}\text { Morphological or } \\
\text { syntactic spelling errors } \\
\text { Capital letter usage rules } \\
\text { Authenticate the claims } \\
\text { Recognizing problem } \\
\text { Attention deficiency } \\
\text { disorder } \\
\text { Thought generation } \\
\text { problem }\end{array}$ & $\begin{array}{c}\text { Spelling } \\
\text { mistake } \\
\text { Punctuation } \\
\text { problem } \\
\text { Capitalization } \\
\text { Hedging } \\
\text { Graphomotor } \\
\text { problem } \\
\text { Cognitive } \\
\text { problem } \\
\text { Psychomotor } \\
\text { problem }\end{array}$ \\
\hline
\end{tabular}

Based on the students' perception, these themes were collected from semi-structured interviews and focused group discussions. These themes reflect the own judgments of students' writing capability in English. They face a lot of difficulties when writing and there are different reasons for their L2 writing difficulties. The participants in a semi-structured interview and focus group discussion replied that they get difficulties in writing as they are not competent and they have less knowledge of grammar and sentence structure, on semantic sophistication, paragraph setting, idea, coherence \& cohesion, fragment, Run-on, subject-verb-agreement, spelling mistake, punctuation problem, capitalization, hedging. Some of them have graphomotor problem, cognitive problem, and psychomotor problem which are 
beyond the academic problem but it has significant impact on academic writing difficulty. In the survey questionnaire, there were 52 questions related to students' writing problems. Questionnaire was consisted of 13 type's problems and each of them contained 4 statements. The result of all questions were categorized into two tables: Table VII and Table VIII. The descriptive analysis of Table VII and VIII represented the types of problem, mean, and the answer of respondents for each statement.

Table VII: Overall L2 writing problems among TL-Students

\begin{tabular}{clcc}
\hline Sequence & Mechanical Problem & Mean & Interpretation \\
\hline 1 & Problem in punctuation & 3.4875 & Medium Problem \\
2 & Problem in indentation & 3.7875 & Low Problem \\
3 & Problem in word-spelling & 4 & Low Problem \\
4 & Problem in capitalization & 3.75 & Low Problem \\
5 & Problem in grammar & 4.025 & Low Problem \\
\hline
\end{tabular}

Table VIII: Overall L2 writing problems among TL-Students

\begin{tabular}{clcc}
\hline Sequence & Rhetorical Problem & Mean & Interpretation \\
\hline 6 & Problem in idea-generation & 3.85 & Low Problem \\
7 & Problem in argumentation & 3.85 & Low Problem \\
8 & Problem in voice & 4.05 & Low Problem \\
9 & Problem in word choice & 4.25 & Very Low Problem \\
10 & Problem in sentence fluency & 3.3875 & Low Problem \\
11 & Problem in presentation & 3.7 & Low Problem \\
12 & Problem in creating purpose & 3.2625 & Medium Problem \\
13 & Problem in Audience & 3.225 & Medium Problem \\
\hline
\end{tabular}

The Table VII and VIII above answered my research question. Table VII shows students' inability to use mechanical grammar in their writing. Table VIII represents students' difficulties in applying rhetorical grammar in their writing. The findings of this study are formulated into the table VII and table VIII. It was concluded that tertiary level students did not face many problems in mechanical grammar and rhetorical grammar. It was found that the overall mean score $(\mathrm{X}=3.74038)$ indicates students had low writing problems in both mechanical and rhetorical problems. A description of university students' writing difficulties based on each item from each type of problems is as follows: The descriptive analysis of survey questionnaire resulted in following data that captured in the following tables:

Table IX: Findings of punctuation problem among university students

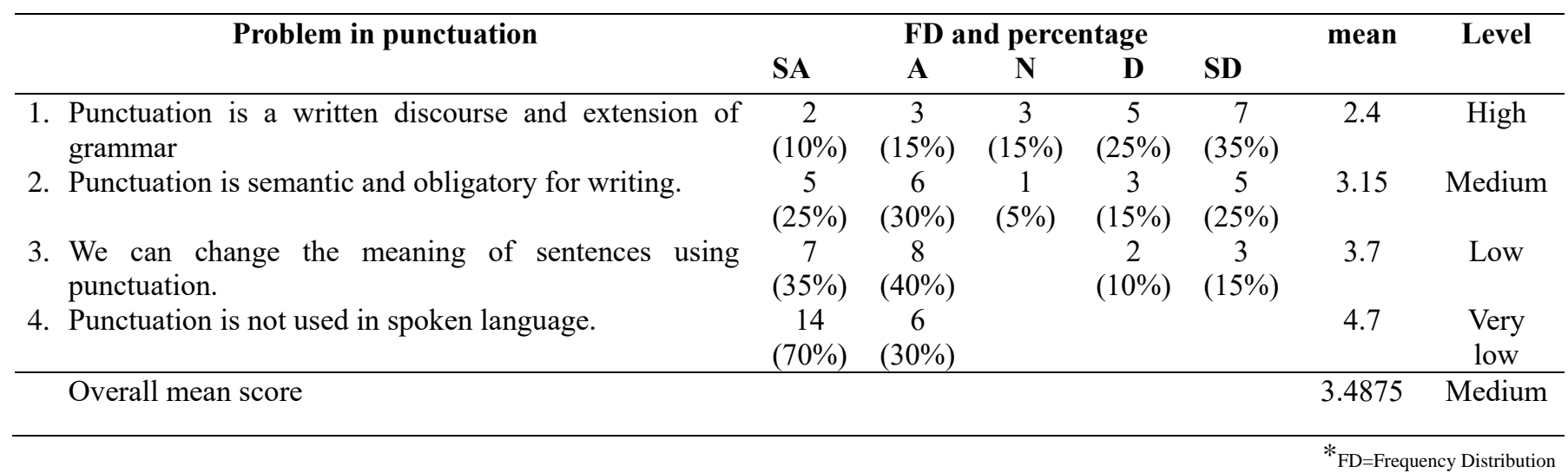

By looking at the results as shown above, the overall mean of punctuation was 3.4875 , which was a medium level problem. It meant some students of university faced medium difficulties in writing. On the other hand, one item or statement of punctuation problems was leveled as a high level problem.

Table X: Findings of indentation problem among university students 


\begin{tabular}{|c|c|c|c|c|c|c|c|}
\hline \multirow[t]{2}{*}{ Problem in indentation } & \multicolumn{5}{|c|}{ FD and percentage } & \multirow[t]{2}{*}{ mean } & \multirow[t]{2}{*}{ Level } \\
\hline & $\mathbf{S A}$ & $\mathbf{A}$ & $\mathbf{N}$ & $\mathbf{D}$ & SD & & \\
\hline $\begin{array}{l}\text { 5. Indentation is space between a } \\
\text { margin to margin and starting of a } \\
\text { line. }\end{array}$ & $\begin{array}{c}12 \\
(60 \%)\end{array}$ & $\begin{array}{c}6 \\
(30 \%)\end{array}$ & & $\begin{array}{c}1 \\
(5 \%)\end{array}$ & $\begin{array}{c}1 \\
(5 \%)\end{array}$ & 4.35 & $\begin{array}{l}\text { Very } \\
\text { Low }\end{array}$ \\
\hline $\begin{array}{l}\text { 6. It means inserting a line space to } \\
\text { indicate a new paragraph. }\end{array}$ & $\begin{array}{c}6 \\
(30 \%)\end{array}$ & $\begin{array}{c}9 \\
(45 \%)\end{array}$ & $\begin{array}{c}1 \\
(5 \%)\end{array}$ & $\begin{array}{c}1 \\
(5 \%)\end{array}$ & $\begin{array}{c}3 \\
(15 \%)\end{array}$ & 3.7 & Low \\
\hline $\begin{array}{l}\text { 7. Hanging indentation is the opposite } \\
\text { of first line indentation. }\end{array}$ & $\begin{array}{c}3 \\
(15 \%)\end{array}$ & $\begin{array}{c}3 \\
(15 \%)\end{array}$ & $\begin{array}{c}4 \\
(20 \%)\end{array}$ & $\begin{array}{c}2 \\
(10 \%)\end{array}$ & $\begin{array}{c}8 \\
(40 \%)\end{array}$ & 2.55 & High \\
\hline $\begin{array}{l}\text { 8. It is a standard paragraph break that } \\
\text { makes writing easier for readers. }\end{array}$ & $\begin{array}{c}16 \\
(80 \%)\end{array}$ & $\begin{array}{c}2 \\
(10 \%) \\
\end{array}$ & & $\begin{array}{c}1 \\
(5 \%)\end{array}$ & $\begin{array}{c}1 \\
(5 \%)\end{array}$ & 4.55 & $\begin{array}{l}\text { Very } \\
\text { Low }\end{array}$ \\
\hline Overall mean score & & & & & & 3.7875 & Low \\
\hline
\end{tabular}

By looking at the results as shown above in the table X, the overall mean of indentation was 3.7875 that was categorized as low problem. It meant some universities had low difficulties in writing. In contrast, one statement of indentation errors was leveled as a high level problem.

Table XI: Findings of spelling error among university students

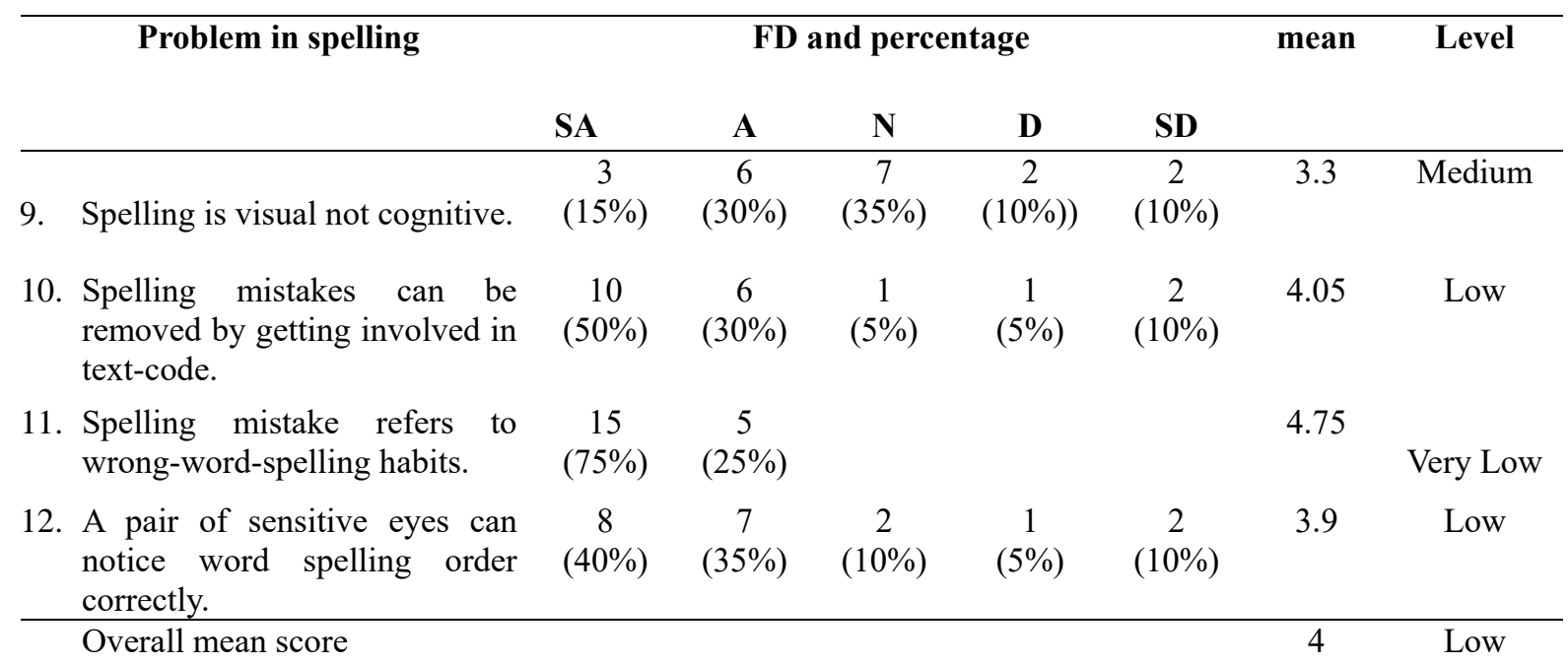

By looking at the results as shown above in table XI, the overall mean of spelling error was $(\mathrm{X}=4.00)$ that was categorized as a low level problem. It means students had little difficulties regarding spelling issues in their writing

Table XII: Findings of capital letter error among university students

\begin{tabular}{|c|c|c|c|c|c|c|c|}
\hline \multirow[t]{2}{*}{ Problem in capital letter } & \multicolumn{5}{|c|}{ FD and percentage } & \multirow[t]{2}{*}{ mean } & \multirow[t]{2}{*}{ Level } \\
\hline & SA & $\mathbf{A}$ & $\mathbf{N}$ & D & SD & & \\
\hline $\begin{array}{l}\text { 13. Capital letters are useful signals } \\
\text { for readers. }\end{array}$ & $\begin{array}{c}14 \\
(70 \%)\end{array}$ & $\begin{array}{c}2 \\
(20 \%)\end{array}$ & $\begin{array}{c}2 \\
(20 \%)\end{array}$ & $\begin{array}{c}1 \\
(5 \%))\end{array}$ & $\begin{array}{c}1 \\
(5 \%)\end{array}$ & 4.35 & $\begin{array}{l}\text { Very } \\
\text { Low }\end{array}$ \\
\hline $\begin{array}{l}\text { 14. Capitalization depends on } \\
\text { personal understanding and style. }\end{array}$ & $\begin{array}{c}3 \\
(15 \%)\end{array}$ & $\begin{array}{c}6 \\
(30 \%)\end{array}$ & $\begin{array}{c}4 \\
(20 \%)\end{array}$ & $\begin{array}{c}2 \\
(10 \%)\end{array}$ & $\begin{array}{c}5 \\
(25 \%)\end{array}$ & 3 & Medium \\
\hline $\begin{array}{l}\text { 15. Capitalization actually lets the } \\
\text { readers know a sentence is } \\
\text { starting. }\end{array}$ & $\begin{array}{c}10 \\
(50 \%)\end{array}$ & $\begin{array}{c}7 \\
(35 \%)\end{array}$ & $\begin{array}{c}1 \\
(5 \%)\end{array}$ & $\begin{array}{c}1 \\
(5 \%)\end{array}$ & $\begin{array}{c}1 \\
(5 \%)\end{array}$ & 4.2 & $\begin{array}{l}\text { Very } \\
\text { Low }\end{array}$ \\
\hline $\begin{array}{l}\text { 16. Capital letters show important } \\
\text { words and signal proper names. }\end{array}$ & $\begin{array}{c}8 \\
(40 \%)\end{array}$ & $\begin{array}{c}3 \\
(15 \%)\end{array}$ & $\begin{array}{c}3 \\
(15 \%)\end{array}$ & $\begin{array}{c}2 \\
(10 \%)\end{array}$ & $\begin{array}{c}4 \\
(20 \%)\end{array}$ & 3.45 & Medium \\
\hline
\end{tabular}

By looking at the results as shown above in table XII, the overall mean of capital letter related problems was 3.75 that was categorized as low level problems. It meant some students of university had low level difficulties in writing. However, two items among four 
statements represented that students faced very low level problems in using capital letter in their writing. On the other hand, two statements showed that students suffered medium level problems in terms of using capital letters.

Table XII: Findings of grammatical error among university students

\begin{tabular}{|c|c|c|c|c|c|c|c|}
\hline \multirow[t]{2}{*}{ Problem in grammar } & \multicolumn{5}{|c|}{ FD and percentage } & \multirow[t]{2}{*}{ mean } & \multirow[t]{2}{*}{ Level } \\
\hline & SA & $\mathbf{A}$ & $\mathbf{N}$ & D & SD & & \\
\hline $\begin{array}{l}\text { 17. Grammar builds trust and for } \\
\text { communication trust is must. }\end{array}$ & $\begin{array}{c}5 \\
(25 \%)\end{array}$ & $\begin{array}{c}11 \\
(55 \%)\end{array}$ & & $\begin{array}{c}1 \\
(5 \%))\end{array}$ & $\begin{array}{c}3 \\
(15 \%)\end{array}$ & 3.7 & Low \\
\hline $\begin{array}{l}\text { 18. Grammar is a set of rules for } \\
\text { syntax and word formation. }\end{array}$ & $\begin{array}{c}8 \\
(40 \%)\end{array}$ & $\begin{array}{c}10 \\
(50 \%)\end{array}$ & $\begin{array}{c}2 \\
(10 \%)\end{array}$ & & & 4.3 & $\begin{array}{l}\text { Very } \\
\text { Low }\end{array}$ \\
\hline $\begin{array}{l}\text { 19. It provides a common code of } \\
\text { conduct for } \\
\text { communication. }\end{array}$ & $\begin{array}{c}6 \\
(30 \%)\end{array}$ & $\begin{array}{c}12 \\
(60 \%)\end{array}$ & $\begin{array}{c}1 \\
(5 \%)\end{array}$ & & $\begin{array}{c}1 \\
(5 \%)\end{array}$ & 4.1 & Low \\
\hline $\begin{array}{l}\text { 20. It prevents language from slipping } \\
\text { into chaos. }\end{array}$ & $\begin{array}{c}9 \\
(45 \%) \\
\end{array}$ & $\begin{array}{c}7 \\
(35 \%) \\
\end{array}$ & $\begin{array}{c}1 \\
(5 \%) \\
\end{array}$ & $\begin{array}{c}1 \\
(5 \%) \\
\end{array}$ & $\begin{array}{c}2 \\
(10 \%) \\
\end{array}$ & 4 & Low \\
\hline Overall mean score & & & & & & 4.025 & Low \\
\hline
\end{tabular}

By looking at the results as shown above in table XIII, the overall mean of grammar error was $(\mathrm{X}=4.025)$ that was categorized as a low level problem. It meant some university students did not have a significant amount of grammatical problems.

Table XIV: Findings of ide generation problem among university students

\begin{tabular}{|c|c|c|c|c|c|c|c|}
\hline \multirow[t]{2}{*}{ Problem in idea } & \multicolumn{5}{|c|}{ FD and percentage } & \multirow[t]{2}{*}{ mean } & \multirow[t]{2}{*}{ Level } \\
\hline & $\mathbf{S A}$ & $\mathbf{A}$ & $\mathbf{N}$ & D & SD & & \\
\hline $\begin{array}{l}\text { 21. An idea is personal thought, } \\
\text { belief, opinion, and plan. }\end{array}$ & $\begin{array}{c}2 \\
(10 \%)\end{array}$ & $\begin{array}{c}10 \\
(50 \%)\end{array}$ & $\begin{array}{c}2 \\
(10 \%)\end{array}$ & $\begin{array}{c}1 \\
(5 \%))\end{array}$ & $\begin{array}{c}5 \\
(25 \%)\end{array}$ & 3.15 & Medium \\
\hline $\begin{array}{l}\text { 22. It is the main point of a piece of } \\
\text { writing. }\end{array}$ & $\begin{array}{c}15 \\
(75 \%)\end{array}$ & $\begin{array}{c}5 \\
(25 \%)\end{array}$ & & & & 4.75 & Very Low \\
\hline $\begin{array}{l}\text { 23. idea says the purpose and } \\
\text { declares the directions of the } \\
\text { essay }\end{array}$ & $\begin{array}{c}5 \\
(25 \%)\end{array}$ & $\begin{array}{c}10 \\
(50 \%)\end{array}$ & $\begin{array}{c}1 \\
(5 \%)\end{array}$ & $\begin{array}{c}1 \\
(5 \%)\end{array}$ & $\begin{array}{c}3 \\
(15 \%)\end{array}$ & 3.65 & Low \\
\hline $\begin{array}{l}\text { 24. It is often stated in the thesis } \\
\text { statement or topic sentence that } \\
\text { is usually located at the end of } \\
\text { paragraph. }\end{array}$ & $\begin{array}{c}4 \\
(20 \%)\end{array}$ & $\begin{array}{c}12 \\
(60 \%)\end{array}$ & $\begin{array}{c}2 \\
(10 \%)\end{array}$ & $\begin{array}{c}1 \\
(5 \%)\end{array}$ & $\begin{array}{c}1 \\
(5 \%)\end{array}$ & 3.85 & Low \\
\hline Overall mean score & & & & & & 3.85 & Low \\
\hline
\end{tabular}

By looking at the results as shown above in table XIV, the overall mean of idea was $(\mathrm{X}=3.85)$ that was categorized as a low level problem in writing. It means some students of university had low level difficulties in idea generation. However, one of the statements showed that students had medium level problems in ideas-main idea \& supporting idea.

Table XV: Findings of argument error among university students

\begin{tabular}{|c|c|c|c|c|c|c|c|c|}
\hline & \multirow[t]{2}{*}{ Problem in argumentation } & \multicolumn{5}{|c|}{ FD and percentage } & \multirow[t]{2}{*}{ mean } & \multirow[t]{2}{*}{ Level } \\
\hline & & SA & $\mathbf{A}$ & $\mathbf{N}$ & D & SD & & \\
\hline & $\begin{array}{l}\text { By an argument, one can } \\
\text { motivate or reassure someone } \\
\text { of something. }\end{array}$ & $\begin{array}{c}5 \\
(25 \%)\end{array}$ & $\begin{array}{c}6 \\
(30 \%)\end{array}$ & $\begin{array}{c}2 \\
(10 \%)\end{array}$ & $\begin{array}{c}3 \\
(15 \%))\end{array}$ & $\begin{array}{c}4 \\
(20 \%)\end{array}$ & 3.25 & Medium \\
\hline 26. & $\begin{array}{l}\text { The way of identifying the } \\
\text { main logic of a paragraph is to } \\
\text { find out the statement that } \\
\text { someone wants to establish } \\
\text { based on something. }\end{array}$ & $\begin{array}{c}7 \\
(35 \%)\end{array}$ & $\begin{array}{c}10 \\
(50 \%)\end{array}$ & $\begin{array}{c}2 \\
(10 \%)\end{array}$ & & $\begin{array}{c}1 \\
(5 \%)\end{array}$ & 4.1 & Low \\
\hline 27. & $\begin{array}{l}\text { Argument refers to a particular } \\
\text { claim of someone. }\end{array}$ & $\begin{array}{c}15 \\
(75 \%)\end{array}$ & $\begin{array}{c}1 \\
(5 \%)\end{array}$ & $\begin{array}{c}3 \\
(15 \%)\end{array}$ & & $\begin{array}{c}1 \\
(5 \%)\end{array}$ & 4.45 & Very Low \\
\hline
\end{tabular}




\begin{tabular}{|c|c|c|c|c|c|c|c|}
\hline $\begin{array}{l}\text { 28. By an argument, one can } \\
\text { convince someone to agree } \\
\text { with his or her claim when in } \\
\text { doubt. }\end{array}$ & $\begin{array}{c}5 \\
(25 \%)\end{array}$ & $\begin{array}{c}7 \\
(35 \%)\end{array}$ & $\begin{array}{c}5 \\
(25 \%)\end{array}$ & $\begin{array}{c}1 \\
(5 \%)\end{array}$ & $\begin{array}{c}2 \\
(10 \%)\end{array}$ & 3.6 & Low \\
\hline Overall mean score & & & & & & 3.85 & Low \\
\hline
\end{tabular}

By looking at the results as shown above in table XV, the overall mean of the argument was 3.85 that was categorized as a low level problem. It means some of the university students had low difficulties in terms of using argumentation in their writing. However, one statement showed that students had medium level difficulties in terms of generating arguments.

Table XVI: Findings of voice problem among university students

\begin{tabular}{|c|c|c|c|c|c|c|c|}
\hline \multirow[t]{2}{*}{ Problem in voice } & \multicolumn{5}{|c|}{ FD and percentage } & \multirow[t]{2}{*}{ mean } & \multirow[t]{2}{*}{ Level } \\
\hline & SA & $\mathbf{A}$ & $\mathbf{N}$ & D & SD & & \\
\hline $\begin{array}{l}\text { 29. Voice is the mixture of rhetorical } \\
\text { perspectives, words, syntactic } \\
\text { structure, and tone that makes } \\
\text { sentences in an accurate manner. }\end{array}$ & $\begin{array}{c}2 \\
(10 \%)\end{array}$ & $\begin{array}{c}5 \\
(25 \%)\end{array}$ & $\begin{array}{c}10 \\
(50 \%)\end{array}$ & $\begin{array}{c}1 \\
(5 \%))\end{array}$ & $\begin{array}{c}2 \\
(10 \%)\end{array}$ & 3.2 & Medium \\
\hline $\begin{array}{l}\text { 30. Voices need to be intellectually, } \\
\text { ethically, and rhetorically unique. }\end{array}$ & $\begin{array}{c}12 \\
(60 \%)\end{array}$ & $\begin{array}{c}3 \\
(15 \%)\end{array}$ & & & & 4.45 & $\begin{array}{l}\text { Very } \\
\text { Low }\end{array}$ \\
\hline $\begin{array}{l}\text { 31. A strong voice helps you grab your } \\
\text { readers and establish relationships } \\
\text { with them. }\end{array}$ & $\begin{array}{c}13 \\
(65 \%)\end{array}$ & $\begin{array}{c}6 \\
(30 \%)\end{array}$ & $\begin{array}{c}1 \\
(5 \%)\end{array}$ & & & 4.6 & $\begin{array}{l}\text { Very } \\
\text { Low }\end{array}$ \\
\hline $\begin{array}{l}\text { 32. An academic voice differs your } \\
\text { thought, your word from other } \\
\text { authors. }\end{array}$ & $\begin{array}{c}7 \\
(35 \%)\end{array}$ & $\begin{array}{c}8 \\
(40 \%)\end{array}$ & $\begin{array}{c}3 \\
(15 \%)\end{array}$ & $\begin{array}{c}1 \\
(5 \%)\end{array}$ & $\begin{array}{c}1 \\
(5 \%)\end{array}$ & 3.95 & Low \\
\hline Overall mean score & & & & & & 4.05 & Low \\
\hline
\end{tabular}

By looking at the results as shown above in table XVI, the overall mean of voice was $(\mathrm{X}=4.05)$ that was categorized as a low level problem. It meant some students had a few problems with their voice. However, one statement showed that students had medium level difficulties in the voice. On the other hand, some other students suffered very low voices.

Table XVII: Findings of word choice problem among university students

\begin{tabular}{|c|c|c|c|c|c|c|c|}
\hline \multirow[t]{2}{*}{ Problem in word choice } & \multicolumn{5}{|c|}{ FD and percentage } & \multirow[t]{2}{*}{ mean } & \multirow[t]{2}{*}{ Level } \\
\hline & SA & $\mathbf{A}$ & $\mathbf{N}$ & D & SD & & \\
\hline $\begin{array}{l}\text { 33. The right word creates a vivid } \\
\text { picture in the reader's mind. }\end{array}$ & $\begin{array}{c}15 \\
(75 \%)\end{array}$ & $\begin{array}{c}1 \\
(5 \%)\end{array}$ & $\begin{array}{c}2 \\
(10 \%)\end{array}$ & $\begin{array}{c}1 \\
(5 \%))\end{array}$ & $\begin{array}{c}1 \\
(5 \%)\end{array}$ & 4.4 & $\begin{array}{l}\text { Very } \\
\text { Low }\end{array}$ \\
\hline $\begin{array}{l}\text { 34. A strong, evocative, precise, and } \\
\text { sensible word convinces the } \\
\text { audience. }\end{array}$ & $\begin{array}{c}16 \\
(80 \%)\end{array}$ & $\begin{array}{c}2 \\
(10 \%)\end{array}$ & $\begin{array}{c}1 \\
(5 \%)\end{array}$ & & $\begin{array}{c}1 \\
(5 \%)\end{array}$ & 4.6 & $\begin{array}{l}\text { Very } \\
\text { Low }\end{array}$ \\
\hline $\begin{array}{l}\text { 35. It increases your confidence level; } \\
\text { it conveys your message to the } \\
\text { audience. } \\
\text {. }\end{array}$ & $\begin{array}{c}5 \\
(25 \%)\end{array}$ & $\begin{array}{c}8 \\
(40 \%)\end{array}$ & $\begin{array}{c}3 \\
(15 \%)\end{array}$ & $\begin{array}{c}2 \\
(10 \%)\end{array}$ & $\begin{array}{c}2 \\
(10 \%)\end{array}$ & 3.6 & Low \\
\hline $\begin{array}{l}\text { 36. The clarity of an argument can be } \\
\text { increased through semantically } \\
\text { sophisticated words. }\end{array}$ & $\begin{array}{c}14 \\
(70 \%)\end{array}$ & $\begin{array}{c}3 \\
(15 \%)\end{array}$ & $\begin{array}{c}1 \\
(5 \%)\end{array}$ & $\begin{array}{c}1 \\
(5 \%)\end{array}$ & $\begin{array}{c}1 \\
(5 \%)\end{array}$ & 4.4 & $\begin{array}{l}\text { Very } \\
\text { Low }\end{array}$ \\
\hline Overall mean score & & & & & & 4.25 & $\begin{array}{l}\text { Very } \\
\text { Low }\end{array}$ \\
\hline
\end{tabular}

By looking at the results as shown above in table XVII, the overall mean of semantic sophistication was $(\mathrm{X}=4.25)$ that was categorized as a very low level problem. It means students of university had very less difficulties in writing.

Table XVIII: Findings of sentence crafting problem among university students 


\begin{tabular}{|c|c|c|c|c|c|c|c|c|}
\hline \multirow{2}{*}{\multicolumn{2}{|c|}{ Problem in sentence fluency }} & \multicolumn{5}{|c|}{ FD and percentage } & \multirow[t]{2}{*}{ mean } & \multirow[t]{2}{*}{ Level } \\
\hline & & SA & $\mathbf{A}$ & $\mathbf{N}$ & D & SD & & \\
\hline & $\begin{array}{l}\text { A fluent sentence indicates a } \\
\text { variety of sentences that flow } \\
\text { together or live together and one } \\
\text { cannot live without another. }\end{array}$ & $\begin{array}{c}4 \\
(20 \%)\end{array}$ & $\begin{array}{c}5 \\
(25 \%)\end{array}$ & $\begin{array}{c}3 \\
(15 \%)\end{array}$ & $\begin{array}{c}4 \\
(20 \%))\end{array}$ & $\begin{array}{c}4 \\
(20 \%)\end{array}$ & 3.05 & Medium \\
\hline 38. & $\begin{array}{l}\text { It can be recognized by engaging } \\
\text { oneself in extensive reading. }\end{array}$ & $\begin{array}{c}2 \\
(10 \%)\end{array}$ & $\begin{array}{c}6 \\
(30 \%)\end{array}$ & $\begin{array}{c}5 \\
(25 \%)\end{array}$ & $\begin{array}{c}4 \\
(20 \%)\end{array}$ & $\begin{array}{c}3 \\
(15 \%)\end{array}$ & 3 & \\
\hline 39. & $\begin{array}{l}\text { Writing fluency refers to accuracy } \\
\text { and speed of writing. }\end{array}$ & $\begin{array}{c}5 \\
(25 \%)\end{array}$ & $\begin{array}{c}10 \\
(50 \%)\end{array}$ & $\begin{array}{c}1 \\
(5 \%)\end{array}$ & $\begin{array}{c}2 \\
(10 \%)\end{array}$ & $\begin{array}{c}2 \\
(10 \%)\end{array}$ & 3.7 & Low \\
\hline 40. & $\begin{array}{l}\text { Fluent sentences are graceful, } \\
\text { transparent, and linguistically } \\
\text { fine-grained. }\end{array}$ & $\begin{array}{c}8 \\
(40 \%)\end{array}$ & $\begin{array}{c}6 \\
(30 \%)\end{array}$ & $\begin{array}{c}2 \\
(10 \%)\end{array}$ & $\begin{array}{c}2 \\
(10 \%)\end{array}$ & $\begin{array}{c}2 \\
(10 \%)\end{array}$ & 3.8 & Low \\
\hline
\end{tabular}

By looking at the results as shown above in table XVIII, the overall mean of sentence fluency was $(\mathrm{X}=3.3875)$ that was categorized as a low level problem. It means some university students had low level difficulties in terms of sentence crafting. However, two of the statements among four reflected that students had medium level problems in sentence crafting in their writing.

Table XIX: Findings of presenting writing error among university students

\begin{tabular}{|c|c|c|c|c|c|c|c|}
\hline \multirow[t]{2}{*}{ Problem in presentation } & \multicolumn{5}{|c|}{ FD and percentage } & \multirow[t]{2}{*}{ mean } & \multirow[t]{2}{*}{ Level } \\
\hline & SA & $\mathbf{A}$ & $\mathbf{N}$ & D & SD & & \\
\hline $\begin{array}{l}\text { 41. Formal presentation should be } \\
\text { linear and connected to each } \\
\text { other. }\end{array}$ & $\begin{array}{c}7 \\
(35 \%)\end{array}$ & $\begin{array}{c}9 \\
(45 \%)\end{array}$ & $\begin{array}{c}1 \\
(5 \%)\end{array}$ & $\begin{array}{c}1 \\
(5 \%))\end{array}$ & $\begin{array}{c}2 \\
(10 \%)\end{array}$ & 3.9 & Low \\
\hline $\begin{array}{l}\text { 42. Informal writing remains } \\
\text { disconnected or isolated. }\end{array}$ & $\begin{array}{c}5 \\
(25 \%)\end{array}$ & $\begin{array}{c}11 \\
(55 \%)\end{array}$ & $\begin{array}{c}3 \\
(15 \%)\end{array}$ & & $\begin{array}{c}1 \\
(5 \%)\end{array}$ & 3.95 & Low \\
\hline $\begin{array}{l}\text { 43. Written presentation refers to } \\
\text { delivering the discourse in a } \\
\text { formal way. }\end{array}$ & $\begin{array}{c}12 \\
(60 \%)\end{array}$ & $\begin{array}{c}8 \\
(40 \%)\end{array}$ & & & & 4.6 & $\begin{array}{l}\text { Very } \\
\text { Low }\end{array}$ \\
\hline $\begin{array}{l}\text { 44. Presentation of writing is a } \\
\text { personal choice and it entirely } \\
\text { depends on the author. }\end{array}$ & $\begin{array}{c}2 \\
(10 \%)\end{array}$ & $\begin{array}{c}5 \\
(25 \%)\end{array}$ & $\begin{array}{c}1 \\
(5 \%)\end{array}$ & $\begin{array}{c}2 \\
(10 \%)\end{array}$ & $\begin{array}{c}10 \\
(50 \%)\end{array}$ & 2.35 & High \\
\hline
\end{tabular}

By looking at the results as shown above in table XIX, the overall mean of presentation was $(\mathrm{X}=3.7)$ that was categorized as a low level problem. It means some university level students had low difficulties in terms of writing presentation style. However, one of the statements among four reflected that students had high level problems in the presentation style of writing.

Table XX: Findings of purpose problem among university students

\begin{tabular}{lcccccccc}
\hline Problem in purpose & \multicolumn{7}{c}{ FD and percentage } & \multicolumn{3}{c}{ mean } & Level \\
& SA & A & N & D & SD & & \\
\hline 45. It clarifies authors' writing & 8 & 9 & 2 & & 1 & 4.15 & Very \\
objectives. & $(40 \%)$ & $(45 \%)$ & $(10 \%)$ & & $(5 \%)$ & & Low \\
46. You should think about your & 5 & 10 & 1 & 2 & 2 & 3.7 & Low \\
$\begin{array}{l}\text { writing purpose asking the } \\
\text { question-Why am I writing for? }\end{array}$ & $(25 \%)$ & $(50 \%)$ & $(5 \%)$ & $(10 \%)$ & $(10 \%)$ & & \\
47. The purpose of writing can be & 2 & 7 & 3 & 2 & 6 & 2.85 & High \\
$\begin{array}{l}\text { many kinds. } \\
\text { 48. It refers to persuade, to inform, } \\
\text { to convince, and to instruct the } \\
\text { readers. }\end{array}$ & $(10 \%)$ & $(35 \%)$ & $(15 \%)$ & $(10 \%)$ & $(30 \%)$ & & High \\
\hline
\end{tabular}

By looking at the results as shown above in table $\mathrm{XX}$, the overall mean of purpose of writing was $(\mathrm{X}=3.2625)$ that was categorized as a medium level problem. It means some university level students had medium level difficulties in terms of thinking and the purpose of 
writing. In addition, two statements presented that students had high level problems in remembering the purpose of writing. However, one of the statements among four reflected that the student had a very low level problem in purpose of writing.

Table XXI: Findings of audience issues among university students

\begin{tabular}{|c|c|c|c|c|c|c|c|}
\hline \multirow[t]{2}{*}{ Problem in Audience } & \multicolumn{5}{|c|}{ FD and percentage } & \multirow[t]{2}{*}{ mean } & \multirow[t]{2}{*}{ Level } \\
\hline & SA & $\mathbf{A}$ & $\mathbf{N}$ & D & SD & & \\
\hline $\begin{array}{l}\text { 49. The audience refers to person } \\
\text { who reads writing. }\end{array}$ & $\begin{array}{c}6 \\
(30 \%)\end{array}$ & $\begin{array}{c}9 \\
(45 \%)\end{array}$ & $\begin{array}{c}1 \\
(5 \%)\end{array}$ & $\begin{array}{c}1 \\
(5 \%)\end{array}$ & $\begin{array}{c}3 \\
(15 \%)\end{array}$ & 3.7 & Low \\
\hline $\begin{array}{l}\text { 50. You should think about your } \\
\text { audience using the question- } \\
\text { who I am writing it for? }\end{array}$ & $\begin{array}{c}5 \\
(25 \%)\end{array}$ & $\begin{array}{c}9 \\
(45 \%)\end{array}$ & & $\begin{array}{c}1 \\
(5 \%)\end{array}$ & $\begin{array}{c}5 \\
(25 \%)\end{array}$ & 3.4 & Medium \\
\hline $\begin{array}{l}\text { 51. Your language of essay should } \\
\text { be changed according to the } \\
\text { audience. }\end{array}$ & $\begin{array}{c}7 \\
(35 \%)\end{array}$ & $\begin{array}{c}3 \\
(15 \%)\end{array}$ & $\begin{array}{c}2 \\
(10 \%)\end{array}$ & $\begin{array}{c}2 \\
(10 \%)\end{array}$ & $\begin{array}{c}6 \\
(30 \%)\end{array}$ & 3.15 & Medium \\
\hline $\begin{array}{l}\text { 52. Audience is the critical } \\
\text { dimension of writing. }\end{array}$ & $\begin{array}{c}5 \\
(25 \%)\end{array}$ & $\begin{array}{c}2 \\
(10 \%)\end{array}$ & $\begin{array}{c}1 \\
(5 \%)\end{array}$ & $\begin{array}{c}5 \\
(25 \%)\end{array}$ & $\begin{array}{c}7 \\
(35 \%)\end{array}$ & 2.65 & High \\
\hline Overall mean score & & & & & & 3.225 & Medium \\
\hline
\end{tabular}

By looking at the results as shown above in table XXI, the overall mean of audience was $(\mathrm{X}=3.225)$ that was categorized as medium level problem. It meant some university level students had medium level difficulties in terms of thinking about the audience.

\section{DISCUSSION}

Foreign language writing difficulties are intimately linked with human psychology. This research paper also found the different sources of writing difficulties from interviews, focus group discussion, survey questionnaire and literature review. The tertiary level students shared their experience of L2 writing difficulties which can be found in the result section. The interview and focus group discussion did not show the major rhetorical grammar problem but it reflected some other problems including mechanical grammar problems.

Survey questionnaire was designed with 52 likert questions. Tertiary level students were invited online to comment on the questionnaire. The likert questions are actually statements. A questionnaire of likert questions was prepared for knowing the perceptions about L2 writing problems of university students. Based on the findings, The 13 types of problems of mechanical grammar and rhetorical grammar: punctuation, indentation, spelling, capitalization, grammar, idea, argument, voice, word choice, sentence fluency, presentation, creating purpose, and audience were realized as a $\mathrm{L} 2$ writing problems considering two types of grammar. It was possible to determine the ultimate result by knowing the perception result from each type. It was found that students only faced 3 types of writing problems more frequently: punctuation, purpose, and audience. It was thought that students did not pay attention carefully to those three types of writing problems.

In case of mechanical grammar, five dimensions were considered: punctuation, indentation, spelling, capitalization, and grammar. To assess proficiency level of students in mechanical grammar, four statements were selected for each dimension. So in total 20 statements were created for five dimensions. For the first dimension, students perceived very good understanding in punctuation that was supported by statement number 3, 4 (We can change meaning of sentences using punctuation, Punctuation is not used in spoken language). On the other hand, the first statement reflected a high level punctuation problem and the 2nd statement showed a medium level punctuation problem among students. Overall punctuation problem among university students was medium. Based on the result of findings from indentation, the problem of indentation was low level and its mean score was 3.7875, which indicated that students perceived considerable knowledge about indentation. In the $3^{\text {rd }}$ dimension, it was observed that tertiary level students of NSU had low level problems in spelling. Students perceived very good understanding in spelling that was supported by statement number 11. Similarly, other two dimensions showed that students did not have significant problems in capitalization and grammatical problems. Based on the result of mechanical grammar, it was concluded that the problem of mechanical grammar was not very much among the students of NSU.

In terms of rhetorical grammar, the 8 dimensions were considered: idea, argument, voice, word choice, sentence fluency, presentation, purpose, and the audience. To assess proficiency level of students in rhetorical grammar, four statements were selected for each dimension. So in total 32 statements were created for eight dimensions. It was observed that tertiary level students of NSU had low level 
problem rhetorical grammar except purpose and audience. Students had medium level problems in purpose and audience. The mean score of purpose was 3.7 and the mean score 3.225 was found from the perception results of the audience. These two dimensions were very important for academic writers. As usual, students perceived misunderstanding in these two dimensions. Because these two dimensions were very simple. This research paper tells us that tertiary level students face mechanical and rhetorical grammar problems including graphomotor problem, cognitive problem, and psychomotor problem.

\section{CONCLUSION}

To conclude the investigation into the problems of writing in English Language in perspective of tertiary level students, students' writing problems were analyzed. And then the purpose of study was completed. Students' problems in writing were finalized based on literature review, findings and descriptive analysis of survey findings, interview findings and focus group discussion findings. After conducting this research, it was concluded that tertiary level students face mostly mechanical grammatical problems and rhetorical grammatical problems. On the other hand, in Bangladesh, at the undergraduate level, students face many obstacles to adjust to a new environment. Most undergraduate students come from a Bengali medium background, which means that they have to adapt to learn writing in English as soon as they are admitted to the university, and at this level, students are pressured to be fluent in the English language. Different socio-economic conditions, cultures, lifestyles, education systems, and mindsets drive students to be problematic and those problems lead to writing difficulties.

\section{A. RECOMMENDATION}

So, based on conclusion, some recommendations were prepared: If two consecutive courses such as reading and writing could have been offered by university and a qualified teacher who has proficiency in both reading and writing could have been recruited, students would have possibilities to overcome those barriers in writing skills. Students should find problems and analyze them. They also should take initiatives to solve those issues in order to be an efficient writer. It was assumed that collaborative teaching practice is a way to overcome the writing difficulties. However, students themselves can sort out the problem and teachers can also help these students.

\section{B. LIMITATION}

There are some limitations to conduct this research. The research participants were chosen from the same university. As the pandemic situation is getting worse, it was not possible to conduct face-to-face interviews and the interview size and sample were limited because the participants were not willing to give interviews on the digital platform. Field work was not done due to COVID-19. All data was collected using digital system. Interview and group discussion were conducted through messenger.

\section{APPENDIX A:}

\section{SURVEY QUESTIONNAIRE FOR MECHANICAL GRAMMAR}

5. Strongly agree

4. Agree

3. Neither agree nor disagree

2. Disagree

1. Strongly disagree

\begin{tabular}{|c|c|c|c|c|c|}
\hline $\begin{array}{l}\text { Please select the statements that represent what you know about the rules of capital } \\
\text { letters. }\end{array}$ & 5 & 4 & 3 & 2 & 1 \\
\hline 1. Capital letters are useful signals for readers. & $\square$ & $\square$ & $\square$ & $\square$ & $\square$ \\
\hline 2. Capitalization depends on personal understanding and style. & $\square$ & $\square$ & $\square$ & $\square$ & $\square$ \\
\hline 3. Capitalization actually lets the readers know a sentence is starting. & $\square$ & $\square$ & $\square$ & $\square$ & $\square$ \\
\hline 4. Capital letters show important words and signal proper names. & $\square$ & $\square$ & $\square$ & $\square$ & $\square$ \\
\hline
\end{tabular}


5. Punctuation is a written discourse and extension of grammar

6. Punctuation is semantic and obligatory for writing.

7. We can change the meaning of sentences using punctuation.

8. Punctuation is not used in spoken language.

Please select the following statements that represent what you know about the rules of $\quad \begin{array}{llllll}5 & 4 & 3 & 2 & 1\end{array}$ indentation.

9. Indentation is blank space between a margin and beginning of a line.

10. It means insert a line space to indicate a new paragraph.

11. Hanging indentation is the opposite of first line indentation.

12. It is a standard paragraph break that makes writing easier for readers.

Please select the following statements that represent how much you are expert in word- $\quad 5 \quad 4 \quad 3 \quad 2 \quad 1$ spelling.

13. Spelling is visual not cognitive.

14. Spelling mistakes can be removed by getting involved in text-code.

15. Spelling mistake refers to wrong-word-spelling habits.

16. A pair of sensitive eyes can notice word spelling order correctly.

Please select the following statements that represent how much you are expert in Grammar.

17. Grammar builds trust and for communication trust is must.

18. Grammar is a set of rules for syntax and word formation.

19. It provides a common code of conduct for public communication.

20. It prevents language from slipping into chaos.

\title{
APPENDIX B:
}

SURVEY QUESTIONNAIRE FOR RHETORICAL GRAMMAR

\author{
5. Strongly agree \\ 4. Agree \\ 3. Neither agree nor disagree \\ 2. Disagree \\ 1. Strongly disagree
}

Please select the statements that represent what you know about the idea.

$\begin{array}{lllll}5 & 4 & 3 & 2 & 1\end{array}$

21. An idea is personal thought, belief, opinion, and plan.

$\square \quad \square \quad \square \quad \square \quad \square$

22. It is the main point of a piece of writing.

23. It states the purpose and sets the directions of the paragraph or passage

24. It is often stated in the thesis statement or topic sentence that is usually located at the end of paragraph.

Please select the statements that represent the level of your proficiency in argument.

25. An argument is an attempt to persuade someone of something.

26. The best way to identify an argument is to locate a statement that someone is trying to establish based on something.

27. An academic argument is your stance, your claim.

28. An argument is used to convince others to agree with your claim or viewpoint when they have doubts or disagreement.

Please select the statements that represent what you know about voice.

29. Voice refers to a rhetorical mixture of point of view, vocabulary, syntax, and tone that

$\begin{array}{lllll}5 & 4 & 3 & 2 & 1\end{array}$
makes phrases, sentences, and paragraphs flow in a particular manner. 
30. Voices need to be intellectually, ethically, and rhetorically unique.

31. A strong voice helps you grab your readers and establish relationships with them.

32. An academic voice differs your thought, your word from other authors.

Please select the statements that represent what you know about sentence fluency.

33. A fluent sentence indicates a variety of sentences that flow together or live together and one cannot live without other.

34. It can be recognized by engaging oneself in extensive reading.

35. Writing fluency refers to accuracy and speed of writing.

36. Fluent sentences are graceful, transparent, and linguistically fine-grained.

\begin{tabular}{|c|c|c|c|c|c|}
\hline $\begin{array}{l}\text { Please select statements that reflect how much you are expertise in semantic } \\
\text { sophistication-word choice. }\end{array}$ & 5 & 4 & 3 & 2 & 1 \\
\hline 37. The right word creates a vivid picture in the reader's mind. & $\square$ & $\square$ & $\square$ & $\square$ & $\square$ \\
\hline 38. A strong, evocative, precise, and sensible word convinces the audience. & $\square$ & $\square$ & $\square$ & $\square$ & $\square$ \\
\hline 39. It increases your confidence level; it conveys your message to the audience. & $\square$ & $\square$ & $\square$ & $\square$ & $\square$ \\
\hline 40. You can increase the clarity of your argument through precise words. & $\square$ & $\square$ & $\square$ & $\square$ & $\square$ \\
\hline
\end{tabular}

Please select the following statements that represent what you know about the
presentation of writing.
writing.

45. It clarifies authors' writing objectives.

46. You should think about your writing purpose asking the question-Why am I writing for?

47. The purpose of writing can be many kinds.

48. It refers to persuade, to inform, to convince, and to instruct the readers.

Please select the statements that represent what you think about the audience.

$\begin{array}{lllll}5 & 4 & 3 & 2 & 1\end{array}$

口 $\quad$ 口 $\quad$ 口 $\quad$ 口

(1)


Gender: $\square$ Male student $\square$ Female Student $\square$ Male Teacher $\square$ Female Teacher

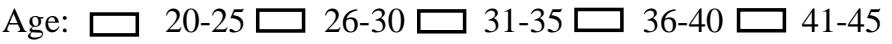

Department:

\section{Interview Questionnaires:}

1. I would like to know a little about you, could you please tell me a brief about you?

2. What do you do?

3. Are you a full time student or part time? How do you pass your normal day?

4. As a researcher, I would like to ask a number of questions regarding L2 writing. If it is alright for you, I can proceed with further questions. Otherwise, I will terminate here. At the moment, How about your L2 writing?

5. If you are enjoying writing in English, it means you are an error free writer. So can you please tell me the techniques that you follow during writing in English?

6. How do you perceive the right version of language?

7. If you are not enjoying writing in English, it means you are not a good writer. It means that you are experiencing difficulties in writing in English, so can you mention the list of problems that you are facing in L2?

8. If you think you have a problem in Grammar or you are facing grammatical problems, which type of grammar bothers you most?

9. Can you please mention the specific portion of grammar that you cannot apply in your writing?

10. What grammatical problems bother you?

11. What would you say is causing your difficulties?

12. Why do you think you experience these difficulties?

13. What do you think causes your problems?

14. Can you think of solutions to your problems?

15. What do you think would help with your L2 writing difficulties?

16. What would help with your difficulties?

17. From your experience, just tell me, who is responsible for L2 writing difficulties?

18. Just let me know, when you see that there are a lot of problems in your English language writing, what happens to you?

19. I believe you know about psychological barriers. If not, let me brief you. Psychological barriers like nervousness, fear, confusion, jealousy, emotional distrust about oneself etc. I think you are personally discomforted when you see that your teacher locates a lot of grammatical problems in your English language writing script. So what psychological barrier do you experience?

20. How do you feel when you see that there are many problems in your writing?

21. In what situation do you think you need to update your English writing skill?

22. I would like to ask a couple of more questions before I conclude the interview. Is there any experience that influences you to improve L2 writing problems in this university?

23. How did you engage in that context?

24. When have you become conscious about English writing difficulties?

25. How have you been conscious about English language writing problems?

26. How have you been conscious about English language writing problems? If there are no further questions, let's start with first questions.

27. Could you please explain for me, what is the best way to teach grammar?

28. What teachers should do when teaching writing in English?

29. Could you please let me know what you should do to solve the English writing problems?

30. In your own perspective, how do you describe English language writing problems?

31. Describe how you would like to change the perception of English writing difficulties?

32. Please give me a brief idea about improving academic writing difficulties. To do so, how much time do we need to fix every day for English writing? What else can we do to improve L2 writing?

\section{The theme of group discussion questions for undergraduate students:}

1. Cause of writing difficulties

2. Effects of writing difficulties to L2 learning

3. Learners' writing problem during writing class, home, assignment and comprehensive exams.

4. Necessary steps to minimize learners' writing difficulties.

7. Useful methods and techniques for developing writing skills

8. Psychological, Physical, and socio-economic problems related to L2 writing.

9. Rhetorical grammar problem, linguistic problem, mechanical grammar problem are considered as a writing problem 
10. Lack of mental health awareness responsible for L2 writing difficulties.

\section{ACKNOWLEDGEMENT}

I would like to express my special thanks of gratitude to my teacher Dr. Sukanto Roy, Dr. Shakila Nur, and Dr. Mohammad shamsuzzaman who instructed me to do this wonderful research on the "investigating into the problems of writing in English Language: Perspective of tertiary level students" that helped me in doing lot of research and I came to know about so many knew things and I am really grateful to them.

\section{REFERENCES}

Afrin, S. (2016). Writing problems of non-English major undergraduate students in Bangladesh: An observation. Open journal of social sciences, 4(3), 104-115._ISSN (Online): 2327-5960, Doi: 10.4236/jss.2016.43016, https://www.scirp.org/journal/jss. Google Scholar Search.

Alfaki, I. M. (2015). University students' English writing problems: Diagnosis and remedy. International Journal of English Language Teaching, 3(3), 40-52. ISSN 20550839 (Online), www.eajournals.org, Google Scholar Search.

Bonjour, R.H., Manuel, A. (2016). Creating and Adapting Resources and Materials for Teaching Writing. International Journal of Research in Economics and Social Sciences (IJRESS), 6(9), 185-194. Research gate.

Chamba, M., Reinoso, M., \& Rengifo, E. (2019). Authentic Materials to Foster Writing Skills in College EFL Learners.12 (6), 112-127. https://doi.org/10.5539/elt.v12n6p112

Dörnyei, Z., \& Taguchi, T. (2009). Questionnaires in second language research: Construction, administration, and processing. Routledge. Google Schoolar

Fareed, M., Ashraf, A., \& Bilal, M. (2016). ESL learners' writing skills: Problems, factors and Suggestions. Journal of Education and Social Sciences, 4(2), 81-92. Zes Rokman Resources (2131022-P), Doi: 10.20547/jess0421604201. ISSN (online): 2410-5676. Researchgate.

Gower, R., Walters, S., \& Phillips, D. (1983). Teaching practice handbook. London: Heinemann. Google Scholar Search. Harmer, J. (2001). The practice of English language teaching. England: Pearson Education Limited. Google Scholar Search.

Harmer, J. (2004). How to teach writing. Pearson Education Limited; England. Google Scholar

Johnson, J. (1996). Why is grammar important? Daily GRAMMAR. http://ask.dailygrammar.com/Why-is-grammar-important.html

Jayousi, A., \& Thaher, M. (2011). Spelling errors of Arab students: Types, causes and teachers' responses (Doctoral dissertation). Google Scholar Search.

Johnson, B. \& Christensen, L.B. (2008). Educational research: Quantitative, qualitative, and mixed approaches. (3rd ed.). Los Angeles: Sage. Google Scholar Search.

Karim, S. M. S., Maasum, T. N. R. T. M., \& Latif, H. (2018). Writing challenges of Bangladeshi Tertiary level EFL learners. Journal of Social Science and Humanities. e-Bangi, 12(2). 296-306. ISSN: 1823-884x. http://ejournal.ukm.my/ebangi/article/view/20435 Google Scholar Search.

Msanjila, Y. P. (2005). Problems of writing in Kiswahili. Nordic Journal of African Studies, 14(1), 11-11. Google Scholar Search.

Naima, A. (2014). Reasons of problems in writing class in the tertiary level of Bangladesh. International Journal of Humanities and Social Science Invention, 3(11), 4148. ISSN (Online):2319-7722, www.ijhssi.org, Google Scholar Search.

Oshima, A., Hogue, A., Wesley, A.(2007). Introduction to Academic Writing. New York: Pearson Education, Inc. Google Scholar Search.

Oshima, A., \& Hogue, A. (2007). Introduction to academic writing (p. 3). Pearson/Longman. Google Scholar Search.

Raimes, A. (1983). Techniques in teaching writing. Oxford University Press, 200 Madison Ave., New York, NY 10016 (ISBN-0-19-434131-3, \$5.95). Google Scholar Search.

Rahman, M., \& Hasan, K. (2019). Academic Writing Difficulties of Bangladeshi Students at a Higher Institution in Malaysia. Journal of Research and Multidisciplinary, 2(2), 145-171. ISSN: 2622-9544 Online, https://journal.alhikam.net/index.php/jrm, Researchgate.

Rahman, M., \& Hasan, K. (2019). Academic Writing Difficulties of Bangladeshi Students at a Higher Institution in Malaysia. Journal of Research and Multidisciplinary, 2(2), 145-171. ISSN: 2622-9544 Online, https://journal.alhikam.net/index.php/jrm

Short, A., \& Nur, S. ( 2020). Secondary English Language Teacher Educators: Voices from Bangladesh. Universal Journal of Educational Research, 8(6): 2251-2260, 2020 https://www.hrpub.org/download/20200530/UJER8-19515200.pdf

Shamsuzzaman, M. (2019, October). Is Writing a Gift? The Daily Star. https://www.thedailystar.net/literature/news/writing-gift-1812433

This publication is licensed under Creative Commons Attribution CC BY.

http://dx.doi.org/10.29322/IJSRP.11.06.2021.p11444

WwW.ijsrp.org 
Shamsuzzaman, M. (2019, May). On Grammar in Writing. The Daily Star. https://www.thedailystar.net/literature/news/grammar-writing-1744966

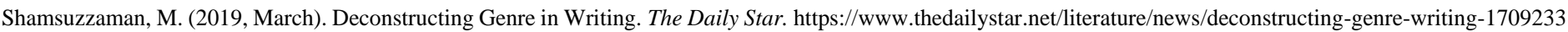

Second-language acquisition. (2021, May 7). In Wikipedia. https://en.wikipedia.org/wiki/Second-language_acquisition

\section{AUTHOR BIOGRAPHY}

\section{Md.Shamim Hossain Biswas}

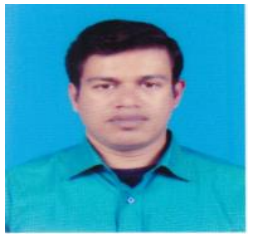

MA in English TESOL, North South University, Bangladesh MSc in Software Engineering, Daffodil International University BSc in Computer Science \& Engineering, Stamford University ORCID: 0000-0002-4595-1470, Cell: +8801531262445.

E-mail: shamim.biswas@northsouth.edu 